\title{
Long-term outcomes of repaired and unrepaired truncus arteriosus: 20-year, single-center experience in Thailand
}

\author{
Ekkachai Dangrungroj ${ }^{1}$, Chodchanok Vijarnsorn ${ }^{\text {Corresp., } 1}{ }^{1}$ Prakul Chanthong ${ }^{1}$, Paweena Chungsomprasong ${ }^{1}$, \\ Supaluck Kanjanauthai ${ }^{1}$, Kritvikrom Durongpisitkul ${ }^{1}$, Jarupim Soongswang ${ }^{1}$, Kriangkrai Tantiwongkosri ${ }^{2}$, \\ Thaworn Subtaweesin $^{2}$, Somchai Sriyoschati ${ }^{2}$ \\ ${ }^{1}$ Department of Pediatrics, Faculty of Medicine Siriraj Hospital, Mahidol University, Bangkok, Thailand \\ 2 Department of Surgery, Faculty of Medicine Siriraj Hospital, Mahidol University, Bangkok, Thailand \\ Corresponding Author: Chodchanok Vijarnsorn \\ Email address: cvijarnsorn@yahoo.com
}

Background: Truncus arteriosus (TA) is a complex congenital heart disease that carries morbidities in the first year of life. Previous authors have reported an operative mortality of $50 \%$. In this report, we aim to report on the survival of patients with TA in our medical center in the recent era.

Methods: A retrospective review of all patients diagnosed with TA in Siriraj Hospital, Thailand from August 1995 to March 2018 was performed. Patients with single ventricle, hemiTA were excluded. The characteristics and outcomes of repaired and unrepaired TA patients with a known recent functional status in 2018 were reviewed. Operative mortality risks were analyzed using a multivariate model.

Results: A total of 74 patients (median age at referral: 70 days) were included in the cohort. One-third of the patients had associated anomalies including DiGeorge syndrome (13.5\%). Anatomical repair was not performed in 22 patients (29.7\%). The median age at time of repair for the 52 patients was 133 days (range: 22 days to 16.7 years). Complex TA was 10\%. Early mortality occurred in 16 patients (30.8\%). Five patients $(9.6 \%)$ had late deaths at $0.3-1.2$ years. Significant mortality risk was weight at time of operation < $4 \mathrm{~kg}$ (HR 3.05, 95\% Cl 1.05-8.74, p-value 0.041). Of the 31 operation survivors, 17 required re-intervention within $0.4-11.4$ years. Eight patients had reoperation at 8.7 years (range: $2.7-14.6$ years) post-repair. Freedom from reoperation was 93\%, 70.4\%, and 31\%, at 5, 10, and 15 years, respectively. All late survivors were in functional class I-II. Of the 22 unrepaired TA patients, 11 patients (50\%) died (median age: 13.6 years; range: 14 days-32.8 years). Survival of unrepaired TA patients was $68.2 \%$, $68.2 \%$, and 56.8, at 5, 10, and 15 years of age, respectively. At the end of study, 11 survivors of TA with palliative treatment had a recent mean oxygen saturation value of $84.1 \pm 4.8 \%$ and a mean weight for height of $81.4 \pm 12.7 \%$, which were significantly lower than those of 31 late-survivors who had undergone anatomical repair.

Conclusion: Contemporary survival rates of patients with TA following operation in the center has been gradually improved over time. Most of the operative mortality occurs in the early postoperative period. Compared to patients with TA who had palliative treatment, operative survivors have a better functional status even though they carry a risk for re-intervention. 
1 Long-term outcomes of repaired and unrepaired truncus arteriosus: 20 -year, single-center 2 experience in Thailand

3 Ekkachai Dangrungroj MD ${ }^{1}$, Chodchanok Vijarnsorn $\mathrm{MD}^{1}$, Prakul Chanthong $\mathrm{MD}^{1}$, Paweena

4 Chungsomprasong $\mathrm{MD}^{1}$, Supaluck Kanjanauthai $\mathrm{MD}^{1}$, Kritvikrom Durongpisitkul MD ${ }^{1}$, Jarupim

5 Soongswang $\mathrm{MD}^{1}$, Kriangkrai Tantiwongkosri $\mathrm{MD}^{2}$, Thaworn Subtaweesin $\mathrm{MD}^{2}$, Somchai

6 Sriyoschati $\mathrm{MD}^{2}$

$7{ }^{1}$ Department of Pediatrics, Faculty of Medicine Siriraj Hospital, Mahidol University, Bangkok,

8 Thailand

92 Department of Surgery, Faculty of Medicine Siriraj Hospital, Mahidol University, Bangkok,

10 Thailand

11 Corresponding Author:

12 Chodchanok Vijarnsorn MD

13 Department of Pediatrics, Faculty of Medicine Siriraj Hospital, Mahidol University

142 Wanglang Rd., Bangkok, Thailand 10700

15 Tel 011-66-2-4197000 ext 5672

16 Fax 011-66-2-4195960

17 Email: cvijarnsorn@yahoo.com

Declarations:

No conflicts of interest were present and financial disclosures were not necessary. 


\section{Abstract}

Background: Truncus arteriosus (TA) is a complex congenital heart disease that carries morbidities in the first year of life. Previous authors have reported an operative mortality of 50\%. In this report, we aim to report on the survival of patients with TA in our medical center in the recent era.

Methods: A retrospective review of all patients diagnosed with TA in Siriraj Hospital, Thailand from August 1995 to March 2018 was performed. Patients with single ventricle, hemiTA were excluded. The characteristics and outcomes of repaired and unrepaired TA patients with a known recent functional status in 2018 were reviewed. Operative mortality risks were analyzed using a multivariate model.

Results: A total of 74 patients (median age at referral: 70 days) were included in the cohort. One-third of the patients had associated anomalies including DiGeorge syndrome (13.5\%). Anatomical repair was not performed in 22 patients $(29.7 \%)$. The median age at time of repair for the 52 patients was 133 days (range: 22 days to 16.7 years). Complex TA was $10 \%$. Early mortality occurred in 16 patients $(30.8 \%)$. Five patients $(9.6 \%)$ had late deaths at $0.3-1.2$ years. Significant mortality risk was weight at time of operation $<4 \mathrm{~kg}$ (HR 3.05, 95\% CI 1.05-8.74, $p$ value 0.041 ). Of the 31 operation survivors, 17 required re-intervention within $0.4-11.4$ years. Eight patients had reoperation at 8.7 years (range: $2.7-14.6$ years) post-repair. Freedom from reoperation was $93 \%, 70.4 \%$, and $31 \%$, at 5, 10, and 15 years, respectively. All late survivors were in functional class I-II. Of the 22 unrepaired TA patients, 11 patients $(50 \%)$ died (median age: 13.6 years; range: 14 days-32.8 years). Survival of unrepaired TA patients was $68.2 \%$, $68.2 \%$, and 56.8 , at 5, 10, and 15 years of age, respectively. At the end of study, 11 survivors of TA with palliative treatment had a recent mean oxygen saturation value of $84.1 \pm 4.8 \%$ and a 
45 mean weight for height of $81.4 \pm 12.7 \%$, which were significantly lower than those of 31 late-

46 survivors who had undergone anatomical repair.

47 Conclusion: Contemporary survival rates of patients with TA following operation in the center

48 has been gradually improved over time. Most of the operative mortality occurs in the early

49 postoperative period. Compared to patients with TA who had palliative treatment, operative

50 survivors have a better functional status even though they carry a risk for re-intervention.

51

52 Key words: Truncus arteriosus, survival, prognosis 
54

55

56

57

\section{Introduction}

Truncus arteriosus (TA) is a rare, complex congenital heart disease characterized by a single great artery supplying both systemic and pulmonary circulations, as the so called common arterial trunk (1). Based on Collett and Edwards' classification (1, 2), TA was classified into four anatomical types originating from the pulmonary artery. However, type IV currently corresponds to pulmonary atresia with ventricular septal defect, which is not precise TA nomenclature.

Clinically, TA leads to cyanosis because of the mixing of deoxygenated and oxygenated blood at the common arterial trunk. Heart failure is inevitable when the pulmonary vascular resistance physiologically declines in infancy. Truncal valve regurgitation and aortic arch anomaly often aggravate heart failure symptoms and mortality (2). If patients were left untreated, pulmonary vascular adaptive mechanisms would lead to rapid pulmonary arterial hypertension and subsequently to Eisenmenger syndrome (ES) (3).

Anatomical repair of TA was reported in 1967 by Rastelli, Titus and McGoon (4) and surgical techniques have progressed steadily since then (5). The timing of the operation tends to be an early repair in neonates or during infancy within the first three months of age to reduce the risk of pulmonary hypertension $(6,7)$. In any case, the surgical procedure is widely known to carry a significant risk of mortality and the operation requires meticulous postoperative management. According to the Society of Thoracic Surgeons Congenital Heart Surgery database (STS-CHSD) from 2000-2009, TA repair with truncal valve surgery had a significantly higher rate of mortality than without truncal valve surgery (30\% vs. 11\%) (8). Furthermore, in a recent multicenter cohort study in the US, $20 \%$ of the children who underwent simple TA repair were reported to experience major adverse cardiac events postoperatively (9). Currently, complex TA 
surgery is categorized as a level-4 procedure according to the Society of Thoracic SurgeonsEuropean Association for Cardio-Thoracic Surgery $(8,9)$.

Siriraj Hospital is one of referral cardiac centers that performs surgical corrections and provides postoperative care for children with TA in Thailand. In a report of early cases prior to 2004, Loahaprasitiporn and colleagues found an operative mortality of 50\% following corrective surgery, within 6 weeks to 6 months of age (10). Medically conservative treatments were provided to patients who did not meet operability criteria, such as late referral with ES. Currently, some survivors in both repaired and unrepaired groups reach adulthood. In the present study, we aim to evaluate: 1) the survival rates of patients who were diagnosed with TA, and either repaired or unrepaired TA, at Siriraj Hospital; and 2) operative mortality risks for the past two decades.

\section{Materials and Methods}

This study was a single-centered, observational study using a hospital database from a large referral cardiac center in Thailand. Following approval from the Siriraj Institutional Review Board Faculty of Medicine, Siriraj Hospital, Mahidol University (COA no. Si 379/2017), all consecutive patients who had a confirmed diagnosis of TA type I - III (Collett and Edward) (1) by echocardiography between August 1, 1995 and March 31, 2018 in the center were retrospectively reviewed. Patients with single ventricle, hemiTA, or TA type IV, or patients who had undergone an operation from another hospital were excluded. The requirement for informed consent from patients was waived with the approval of the Siriraj Institutional Review Board Faculty of Medicine, Siriraj Hospital, Mahidol University. Demographic data was collected for age at referral, diagnosis, gender, weight at referral, oxygen saturation, associated anomalies, presence of DiGeorge syndrome, initial presentation, and cardiac findings including type of TA 
99 (I, II, III), truncal valve leaflets, degree of truncal valve regurgitation, presence of aortic arch 100 interruption, pulmonary artery stenosis, arch sidedness and coronary abnormality. Patient 101 management was recorded, including surgical interventions, postoperative complications, and 102 clinical outcomes including weight, height, functional class, oxygen saturation, and mortality 103 following diagnosis and at the most recent follow-up at the end of 2018. Patients who were lost 104 to a follow-up or their latest functional status was unknown in 2018 were excluded from the 105 study cohort. Early mortality following total correction for TA was defined as 30-day mortality 106 including patients who died after 30 days without being discharged from the hospital when admitted for the operation. Patient information was anonymized and de-identified prior to the 108 analysis.

\section{Statistical analysis}

The patients' baseline characteristics and outcomes were summarized using descriptive

111 statistics. Normally distributed data was presented as mean $\pm \mathrm{SD}$, while the median (with range) was used where the distribution of data was not normal. Categorical data was represented as a number and a percentage $(\%)$. The comparison of continuous variables between groups was assessed using an unpaired $\mathrm{T}$ test for normally distributed data and a Wilcoxon rank-sum test for non-normally distributed data. Differences between the categorical data were assessed with a

116 Chi-square or Fisher's exact test. Patients were classified into two groups; those who underwent 117 anatomical repair for TA and those who had palliative treatment. Cumulative survival, from date 118 of birth and date of operation to the endpoint, was calculated using the Kaplan-Meire analysis with log-rank test. The association between baseline characteristics and postoperative mortality

120 was evaluated with multivariate analysis. A $p$-value $<0.05$ was considered to be statistically 
121 significant. Statistical analyses were performed with SPSS 20.0 for Windows (SPSS Inc.,

122 Chicago, IL, USA).

\section{Results}

\section{Demographics}

A total of 74 patients with TA (45\% were male) was included in the study cohort. Median age of referral and diagnosis at the center was 70 days of age (range: 0-25.9 years). The patients' demographics are summarized in Table 1. Almost one-third of the patient population had an associated anomaly such as VACTREL association, anorectal malformation, tracheoesophageal fistula, micropthalmia, hypospadia, including DiGeorge syndrome (13.5\%). The most common type of TA was type I. Six patients had pulmonary artery stenosis (8.1\%), five patients had moderate or severe truncal valve regurgitation $(6.7 \%)$, four patients had partial anomalous

132 pulmonary venous return (5.4\%), and two patients had interrupted aortic arch (2.7\%). Following

133 the identification of operability and obtaining consent from the patients' parents, 52 patients underwent TA anatomical repair and 22 patients did not. Two patients in the unrepaired TA group underwent palliative pulmonary artery banding (PAB); one was unable to perform further anatomical repair for TA due to underlying Jacobsen syndrome with severe thrombocytopenia while the other died after repair interrupted the aortic arch concurrent with PAB. From observations, the initial oxygen saturation in the repaired TA group was significantly higher than that of the patients who received palliative treatment. The flow of the study is shown in Figure 1.

Figure 1. Flow of the study 


\section{Surgical correction and mortality}

144 Table 2 shows patient demographics, operative data, and early postoperative course in 52

145 repaired TA patients. Anatomical repair of TA has been performed at the medical center since

146 1999. Of the 52 patients, 19 underwent total repair in 1999-2006, representing various age

147 groups at the time of operation: neonate $(n=2)$, aged $1-6$ months old $(n=31)$, aged 6 months -1

148 year old $(n=13)$, age more than 1 year old $(n=6)$. Three patients underwent PAB prior to a total

149 correction. The right ventricular to pulmonary artery valve conduit diameter varied from 12-25

$150 \mathrm{~mm}$, depending on the patient's size, with z-score of $2.3 \pm 0.9$. The types of conduit are shown in

151 Table 2. One patient in the cohort underwent direct anastomosis from right ventricle to

152 pulmonary artery. Repair of complex TA (which is defined as TA with significant pathology of

153 truncal valve and aortic arch $(8,9)$ accounted for 5 of $52(9.6 \%)$ of the cohort. Among four

154 patients who underwent concurrent truncal valve repair, three died postoperatively. The patient

155 who survived (13.9 years postoperatively) had progressive aortic valve (native truncal valve) and

156 conduit regurgitation, and the patient is currently on a list for redo surgery. One patient who

157 underwent concomitant aortic arch repair for interrupted aortic arch died early post-operation due

158 to pulmonary hypertensive crisis. A total of 16 early deaths $(30.8 \%)$ occurred with a median

159 postoperative time of 3 days (range: 0-40 days). Most of the patients with early mortality died

160 from low cardiac output syndrome (LCOS), related to pulmonary hypertensive crisis or

161 myocardial ischemia, followed by sepsis and multi-organ dysfunction (Table 3). All early

162 survivors $(n=36)$ were complete in a follow up with a median duration of 5.7 years (range: $0.46-$

16319.8 years). Late mortality was reported in five patients $(9.6 \%)$ at a median duration of seven

164 months after operation (range: 5.5 months-1.2 years), related to infection and possible persistent

165 pulmonary hypertension postoperatively (Table 3). The postoperative survival of patients with 
166 repaired TA $(\mathrm{n}=52)$ was $63.5 \%$ at 1 -year and steady at $59.5 \%$ after 2 years following the

167 operation. Consequently, survival rates of early survivors $(n=36)$ at $1,5,10$, and 15 years

168 following repair were $91.7 \%, 85.9 \%, 85.9 \%$, and $85.9 \%$, respectively. A univariate analysis of

16917 variables revealed 2 potential risk factors of mortality following repaired TA: weight at

170 operation $<4 \mathrm{~kg}$ and preoperative major infection within 1 month (Table 4 ). The independent

171 risk of postoperative mortality, which was identified by multivariate analysis was only weight at

172 operation < $4 \mathrm{~kg}$ (HR 2.71, 95\% CI 1.05-6.95; $p$-value 0.039) (Table 4). With regards to early

173 death postoperatively, weight at operation $<4 \mathrm{~kg}$ was found to be an associated factor by

174 univariate and multivariate analyses (HR 3.05, 95\% CI 1.05-8.74, p-value 0.041). In patients

175 with late mortality, preoperative major infection within one month and pulmonary hypertensive

176 crisis in the operating room requiring inhaled nitric oxide were shown to be mortality risks by the

177 univariate analysis. Nevertheless, only pulmonary hypertensive crisis in the operating room

178 requiring inhaled nitric oxide was found to be an independent risk factor for late death by the

179 multivariate analysis (hazard ratio 6.59, 95\% CI 1.02-42.7, $p$-value 0.048 ).

180

181

182

183

184

185

186

187

188

\section{Reoperation and reintervention}

Thirty-one late survivors following total correction were reported surviving until the end of 2018 and were having regular follow-ups at the medical center. The median postoperative follow-up was 6.4 years (range: $1.0-19.8$ years). Seventeen patients $(54.8 \%)$ required either catheter intervention or reoperation for conduit change at a median time of 3.1 years postoperation (range: $0.4-11.4$ years). The range in number of catheter interventions was $0-4$ times per patient. Freedom from re-intervention was reported to be $93.3 \%, 48.3 \%, 43.9 \%$, and 35\% at $1,5,10$, and 15 years post-repair, respectively. Reoperation for conduit replacement had been performed in 8 patients $(25.8 \%)$ at the median time of 8.7 years (range: $2.7-14.6$ years) after 
189 their corrective surgery. Freedom from reoperation in survivors with repaired TA was 100\%,

$19093 \%, 70.4 \%$, and $31 \%$ at $1,5,10$, and 15 years postoperation, respectively.

\section{TA with palliative treatment}

192

193

Twenty-two patients in the cohort had not undergone anatomical repair for TA. Cardiac catheterization, which was performed in 6 patients showed mean pulmonary arterial pressure of $70.8 \pm 14.0 \mathrm{mmHg}$, baseline pulmonary vascular resistance index of $20.1 \pm 14.11 \mathrm{WU} \cdot \mathrm{m}^{2}$ and post-pulmonary vasodilator testing pulmonary vascular resistance index of $6.9 \pm 4.9 \mathrm{WU} \cdot \mathrm{m}^{2}$. Some patients who were deemed to be receiving a conservative treatment were referred back to the primary hospital. All 22 patients in this study had been in recent contact and had a known clinical status in 2018. Since their most recent visit (median age: 13.6 years; range: 14 days-32.8 years), 11 patients $(50 \%)$ had died. Seven patients had died in infancy (less than 1.5 years of age), and the primary cause of death was heart failure, precipitated by infections such as sepsis or pneumonia. Four patients who died (13-32.8 years of age) had late referral and diagnoses of ES.

Of the four patients, two died from pneumonia and two patients had sudden death, which was likely related to adverse cardiac events. The survival rates of the TA with palliative treatment were $72.7 \%, 68.2 \%, 68.2 \%$, and 56.8 , at $1,5,10$, and 15 years of age, respectively. In comparing the survival ages of 52 patients with TA repair, $63.5 \%$ were surviving at 1 -year and $59.6 \%$ were steady at 5-years of age, with no statistical differences. The survival of 36 early-survivors following TA repair was significantly higher than that of 22 patients with palliative treatment (Log rank $p$ 0.03). At the end of study cohort in 2018, 11 survivors of TA with palliative treatment had a recent mean oxygen saturation value of $84.1 \pm 4.8 \%$ and a mean weight for height of $81.4 \pm 12.7 \%$, which were significantly lower than those of 31 late-survivors who had undergone anatomical repair. 


\section{Pulmonary arterial hypertension (PAH) therapy}

213

214

215

216

217

218

219

220

221

222

223

224

225

226

227

228

229

230

231

232

233

Of the 52 patients who underwent surgical correction, 47 patients $(90.3 \%)$ received postoperative pulmonary vasodilators including inhaled nitric oxide, iloprost, or oral forms such as sildenafil, bosentan or beraprost sodium. In five patients who had not been given pulmonary vasodilators, four underwent total correction prior to 2000 , when inhaled nitric oxide was unavailable in the theatre and intensive care unit. Sixteen early deaths $(30.8 \%)$ occurred with a median postoperative time of three days (range: 0-40 days), related to pulmonary hypertensive crisis or myocardial ischemia, followed by sepsis and multi-organ dysfunction. Twenty-eight patients were prescribed oral pulmonary vasodilators when they were discharged home after their operation. Monotherapy was given: beraprost in 3 patients and sildenafil in 25 patients. The median time of post-operative pulmonary arterial hypertension therapy was 6.9 months (range 1109 months). Pre-treatment targeted therapy was used in two patients who underwent total correction at age 14 and 16 years, because of late referrals and the decision of parents. They were placed on sildenafil (25-50 mg oral three times/day) prior to the cardiac catheterization in the referral center. Interestingly, both patients had baseline oxygen saturation in room air of 90-94\%. Cardiac catheterization preoperatively showed elevated pulmonary artery pressure (PAP) in both patients. The first patient had a mean PAP (mPAP) of $80 \mathrm{mmHg}$, Qp:Qs of 1.36, and pulmonary vascular resistance $(\mathrm{PVR})$ index of $13.6 \mathrm{WU} \cdot \mathrm{m} 2$ in room air and $\mathrm{mPAP} 72 \mathrm{mmHg}$; the PVR index declined to $0.9 \mathrm{WU} \cdot \mathrm{m} 2$ after inhaled nitric oxide $20 \mathrm{PPM}$ testing. The second patient had a mPAP of $63 \mathrm{mmHg}$, Qp:Qs of 6, PVR of 3.4 WU, and PVR index of $3.9 \mathrm{WU} \bullet \mathrm{m} 2$ in room air. Following surgical repair, these two patients continued with the pulmonary vasodilator (oral sildenafil, for 48.6 and 57.9 months following operation, respectively). Repeat cardiac 
234 catheterizations at two years post repair were performed, with a decreased mean PAP to 30

$235 \mathrm{mmHg}$ in the first patient and $28 \mathrm{mmHg}$ in the second patient.

236 Of the 22 patients who received palliative treatment, 11 were mortality cases; 7 patients

237 died in infancy (less than 1.5 years of age) due to heart failure. These 7 patients had no indication

238 for receiving PAH therapy. Four of the patients who died (13-32.8 years of age) had late referrals

239 and were diagnosed with ES. Of these four patients, two received oral pulmonary vasodilator

240 (one beraprost and one sildenafil). Of the 11 surviving patients, 6 received oral pulmonary

241 vasodilator (3 beraprost and 3 sildenafil).

242 Discussion

In this 20 -year, single-center database, 52 of 74 patients with a diagnosis of TA had undergone total repair at a median age of 133 days (range: 22 days-16.7 years). Repair of complex TA, which required truncal valve repair or aortic arch interruption repair was performed in $10 \%$ of the cases. Early and late mortality was $30.8 \%$ and $9.6 \%$, respectively. Mean survival rate of early repaired TA survivors $(n=36)$ was $91.7 \%$ at 1 -year and $85.9 \%$ at 2 -years postoperatively. The independent risk factor for overall mortality was weight at operation $<4 \mathrm{~kg}$ (hazard ratio: $3.05,95 \%$ CI 1.05-8.74, $p$-value 0.041 ). At the median postoperative time of 6.4 years (range: 1.0-19.8 years), more than half of the late-survivors required either catheter intervention or reoperation for conduit change. Freedom from reoperation in repaired TA survivors was $100 \%, 93 \%, 70.4 \%$, and $31 \%$, at $1,5,10$, and 15 years, respectively. All survivors were in the WHO functional class I-II. Of the 22 patients who had palliative treatment (median age at the most recent visit: 13.6 years; range: 14 days-32.8 years), 11 patients $(50 \%)$ died, with survival rates of $72.7 \%, 68.2 \%, 68.2 \%$, and 56.8 , at $1,5,10$, and 15 years of age. This cohort 
257 the report of Loahaprasittiporn and colleagues who reported early outcomes using the 1995-2004

258 database from our medical center (10). Survival here is shown with aggregated times and

259 numbers of patients. Although the surgical mortality in this study is still high, it is less than the

$26050 \%$ reported previously for our medical center (10). Furthermore, this cohort includes outcomes

261 for unrepaired TA patients. These findings may aid in counseling patients with regards to

262 treatment and prognosis.

The timing of surgical repair of TA has an impact on outcome as early mortality risk is

264

265

266

267

268

269

270

271

272

273

274

275

276

277

278

279 associated with elevated pulmonary vascular resistance leading to postoperative pulmonary hypertensive crisis $(6,7,11)$. Hanley and colleagues indicated that when the age at repair was above 100 days, it was an independent predictor of perioperative death. Moreover, pulmonary artery pressure was significantly lower in patients undergoing the operation during the neonatal period (7), which agrees with the study of Urban who found fewer pulmonary hypertensive episodes in patients with repaired TA under 90 days of age (7\%), in contrast to above 90 days of age $(40 \%)(11)$. Elective repair during the first three months of age is historically advocated in many centers $(12,13)$, though the benefits from repairing TA in the neonatal period is widely accepted $(6,7,11,14)$. In this decade, the median age at the time of anatomical correction of TA has decreased significantly in many medical centers and has favorably affected surgical outcomes $(14,15)$. In developing countries; however, delaying the referral often leads to delaying the operation, which remains a health care issue. At a few centers, prenatal diagnosis has gradually developed, though in our study cohort, only four patients had prenatal diagnoses. The median age of referral to our center tended to decrease from 126 days (0-13.9 years of age) in 1995-2006 to 63.5 days (0-25.9 years of age) after 2006 with increased operable opportunity. The age of the patient at time of operation; however, was mostly during infancy (median: 133 
280

281

282

283

284

285

286

287

288

289

290

291

292

293

294

295

296

297

298

299

300

301

302

days). At our medical center, in 2014, neonatal repairs were initiated and performed in two patients. Unfortunately, one died in hospital and the other had late death at 168 days

postoperatively due to pneumonia. In our study, six patients who survived beyond their first year of life had undergone anatomical repair for TA. Pre-operative cardiac catheterization showed that the mean pulmonary artery pressure was $57.2 \pm 17.6 \mathrm{mmHg}$ and the pulmonary vascular resistance index in room air, and after a pulmonary vasodilator were $6.2 \pm 4.9$ and $1.6 \pm 1.2 \mathrm{WU} \cdot$ $\mathrm{m}^{2}$, respectively. All of these patients survived postoperatively and remained in follow-up until the end of study with a median duration of 5.6 years (range: 4.1-12.7 years). These findings suggest that repair of TA in patients who are older than one year of age is feasible, though physicians need to deliberately select the cases $(16,17)$.

A number of single-center and multicenter studies have recently reported acceptable operative outcomes for patients with TA. In-hospital mortality varied from 5 to $17.5 \%(6,9,14$, $15,18,19)$, and the presence of associated cardiac anomalies, such as interrupted aortic arch, significant truncal valve regurgitation, coronary abnormalities, and pulmonary arteries were reported to increase the operative mortality $(6-8,14)$. In a large cohort of patients with STSCHSD, complex TA (defined as TA with significant aortic arch anomaly, interruption or coarctation, and truncal valve regurgitation requiring concomitant repair) accounted for $10 \%$ of the TA population, carrying an operative mortality of $30 \%$, which is much higher than that of simple TA repair $(6.9-11 \%)(8,9)$. In accordance with a recent report from a Toronto group, the 10-year survival of patients with complex TA (defined as TA with significant aortic arch anomaly, interruption or coarctation, truncal valve regurgitation requiring concomitant repair, and branch pulmonary artery stenosis/ hypoplasia) who had undergone an operation since 2000 was $68 \%$, compared to $95 \%$ for patients who had simple TA (19). The overall operative 
303

304

305

306

307

308

309

310

311

312

313

314

315

316

317

318

319

320

321

322

323

324

325

mortality for these patients decreased from $36 \%$ to $7 \%$ since 2000 , which coincided with the average reduction in cardiopulmonary bypass time. Low birth weight, complex TA, and year of diagnosis prior to 2000 were associated with decreased survival for patients up to one year of age in the study by Morgan and colleagues (19). In a large study from a Melbourne group, 11.7\% early mortality and $11.1 \%$ late death were reported following anatomical repair (14). Weight at repair $<2.5 \mathrm{~kg}$, prior surgical intervention, coronary abnormalities, and use of postoperative extracorporeal membrane oxygenator were found to be risk factors for early death while DiGeorge syndrome was a risk factor for late death (14). Comparing to our initial report from our medical center (10), early mortality following TA repair was reduced from $50 \%$ to $30.8 \%$. This decrease was greater than that recently reported for experienced centers $(8,9,14,15,17$, 19), but comparable to the 2016 publication from Asagai and colleagues who reviewed 52 patients with repaired TA between 1974 and 2002 (18). The plausible explanation may be because both Asagai's (18) and ours report had mostly included patients who were beyond the neonatal period. Pulmonary hypertensive crisis and LCOS, followed by precipitated infection were the main causes of early death. The independent risk factor for overall mortality was weight at operation $<4 \mathrm{~kg}$ (HR 3.05, 95\% CI 1.05-8.74, p-value 0.041). Complex TA, coronary abnormality, and extracardiac associated anomalies were not found to be strong predictors of death in our study. The number of truncal valve and interrupted arch repairs in our study was only five, which may have been too small a sample size to demonstrate a statistic difference in the multivariate analysis. The reports of late death $(9.6 \%)$ were consistent with several other previous studies $(14,15,18,20)$. been long debated $(6,13,21,22)$. Homograft conduit provides good biocompatibility, stable 
326 hemodynamic, and a competent valve to deal with the elevated pulmonary pressure in TA;

327 however, its poor growth potential, especially in TA repair that is usually performed in infancy,

328 leads to an unsatisfactory freedom from reoperation (21). Heterograft valve conduit has been

329 developed and may be used based on material limitations and the desired size of the homograft.

330 Drawbacks have been reported such as possible unfavorable biocompatibility resulting in

331 pseudomembrane formation, aneurysm, and thrombosis and its poor longevity (22). The direct

332 anastomosis technique without extracardiac conduit was proposed by Barbero-Marcial (23), and

333 it may overcome the limited growth of conduit and decrease the need for reintervention (24),

334 though progressive pulmonary regurgitation, postoperative pulmonary branch stenosis, and

335 compression to the left anterior descending artery, especially in patients with coronary

336 abnormalities, remain as significant issues $(13,15)$. In our medical center, homografts were used

337 in 15 patients (28\%) and heterografts were used in 36 patients (69\%). Of the 36 heterografts, 24

338 patients who underwent the operation after 2010 were repaired with a Contegra bovine valve

339 conduit. Conduit size selection in the center was within z-score of $2.3 \pm 0.9$, which was within

340 the acceptable range mentioned in previous publications $(21,22)$. One patient in this cohort who

341 underwent TA repair with direct anastomosis at 49 days of age died early postoperatively due to

342 pulmonary hypertensive crisis, sepsis, and myocardial failure with atrial tachycardia followed by

343 idioventricular rhythm. In some cases, following TA repair, re-intervention may be performed to

344 conduit and branch the pulmonary arteries $(5,14,15,19,20)$. Catheter intervention such as

345 balloon dilatation or stent implantation may be initially used at our center in the management to

346 alleviate stenotic lesions as a strategy for delaying reoperation. At the median postoperative

347 duration (6.4 years; range: 1.0-19.8 years), the freedom from re-intervention in the study was

$34848.3 \%$ and $43.9 \%$, at 5 and 10 years, respectively, which is consistent with previous reports (8, 
$34914,15,19)$. Reoperation for conduit replacement was performed in 8 patients $(25.8 \%)$ at a

350 median time of 8.7 years (range: $2.7-14.6$ years) post total correction. Freedom from reoperation

351 in survivors with repaired TA at 10 years was $70.4 \%$. With regards to truncal valve reoperation,

352 a 14-year-old patient who had undergone concomitant truncal valve repair with primary TA

353 repair, was on a list for reoperation to change the conduit and redo the truncal valve repair at 13

354 years from the first operation. Among those with a less than moderate truncal valve, 1 patient

355 had infective endocarditis with vegetation at the truncal valve, requiring late truncal valve repair

356 and conduit change at 5.2 years post-operation, and 1 patient had progressive to moderate truncal

357 regurgitation with stable hemodynamic.

Of 22 patients who had TA with palliative treatment, 12 patients were definitely late

diagnosed and then referred, which led to a progression of the disease to severe pulmonary

360

arterial hypertension or Eisenmenger syndrome, where total repair should not be performed. Four

patients were referred in infancy, and were on the list for TA repair, but they died while waiting

for surgery due to infection and multi-organ failure at their local hospital. Three patients were diagnosed and then referred as neonates, but they died from neonatal sepsis/NEC/pneumonia in

the center. The parents of two patients denied surgery for their children. One patient had

Jacobsen syndrome with severe thrombocytopenia, which has a high risk for major surgery. The

parents agreed to have palliative pulmonary artery banding to alleviate heart failure symptoms.

The economic burden may play a role in late diagnoses and referrals and in the decision to deny surgery in the earlier era. The fate of patients with palliative treatment for TA was also a focus of age due to intractable heart failure and infection. The second group $(n=4)$ died at 10-years and 
372 publications, almost $80 \%$ of the patients with unrepaired TA died before 1 year of age and few

373 survived until adulthood $(3,25,26)$. Niwa and colleagues reviewed 10 adults with ES secondary

374 to unrepaired TA and found the mean age of survival was $41.5 \pm 5.1$ years, which was a shorter

375 life-span compared to ES secondary to ventricular septal defect (25). In our series, the survival

376 rates of 22 patients with unrepaired TA were $72.7 \%, 68.2 \%, 68.2 \%$, and 56.8 at $1,5,10$, and 15

377 years of age. Half of these patients were deceased at an estimated $15.2 \pm 3.8$ years of age

378 (median $\pm \mathrm{SE}$ ). All survivors that were encountered progressed to the ES stage that led to

379 hypoxemia and limited somatic growth. In comparing the ages of survival for patients with

380 repaired and unrepaired TA, no statistical difference was found since most of the operative

381 mortalities included late death occurring before 2 years of age. The survival curve of 36 early

382 survivors following TA repair was superior to that of 22 patients with palliative treatment (Log

383 rank $\mathrm{p}=0.03$ ). Therefore, complete repair of TA likely improves the survival of patients with TA.

384 To improve public health outcomes for patients with this lesion, early detection and referral can

385 help manage and repair the lesion in patients who are neonates or at least younger than three

386 months of age. The optimal surgical and postoperative care in neonates and infants in the center

387 is the main focus.

388 Limitations

Selective bias is inevitable in retrospective studies. Consequently, we included patients with diagnoses of TA type I, II, or III who had undergone TA repair or received palliative treatment at the medical center. All patients were in follow-up or their functional status was

392 known at the end of study (2018). The small number of patients in the study affected the multivariate analysis. In addition, the age of referral and diagnosis of TA at the center is mainly

394 known for patients who were older than neonate, because of the limited resources available in the 
395 developing country. Management and surgical strategies also tend to be inconsistent, as they

396 often depend on the preferences of individual surgeons and pediatric cardiologists.

\section{Conclusion}

Contemporary survival rates of patients with TA following operation in the center has

been gradually improved over time. Most of the operative mortality occurs in the early

400

postoperative period. Compared to patients with TA who had palliative treatment, operative

401

survivors have a better functional status even though they carry a risk for re-intervention. Weight

at operation under $4 \mathrm{~kg}$ is identified as a significant early and all-mortality risk factor. The

survival rate of patients with repaired TA, who can be discharged from hospital after their

operation is better than patients with unrepaired TA. We encourage primary physicians to detect

this lesion as early as possible for the optimal repair and management.

406

407

408

409

410

411

412

413

\section{Acknowledgements}

The authors thank the faculty and staff of the Cardiovascular Thoracic Surgery, Faculty of Medicine Siriaj Hospital for their support and care of patients with TA. We acknowledge Prof. Duangmanee Loahaprasitiporn, Deputy Dean of Quality Development, Faculty of Medicine Siriaj Hospital, who established the original research and published the preliminary outcomes of patients with TA in Siriraj Hospital since 2008. We also thank Miss Julaporn Poolium who greatly assisted in the statistical analysis.

No conflicts of interest were present and no financial disclosures were necessary. 


\section{References}

416 1. Collett RW, Edwards JE. Persistent truncus arteriosus; a classification according to

417 anatomic types. Surg Clin North Am. 1949;29(4):1245-70.

418 2. Jacobs ML. Congenital Heart Surgery Nomenclature and Database Project: truncus

419 arteriosus. Ann Thorac Surg. 2000;69(4 Suppl):S50-5.

420 3. Marcelletti C, McGoon DC, Mair DD. The natural history of truncus arteriosus.

421 Circulation. 1976;54(1):108-11.

422 4. Rastelli GC, Titus JL, McGoon DC. Homograft of ascending aorta and aortic valve as a

423 right ventricular outflow. An experimental approach to the repair of truncus arteriosus. Arch 424 Surg. 1967;95(5):698-708.

425 5. Mavroudis C, Jonas RA, Bove EL. Personal glimpses into the evolution of truncus 426 arteriosus repair. World J Pediatr Congenit Heart Surg. 2015;6(2):226-38.

427 6. Brown JW, Ruzmetov M, Okada Y, Vijay P, Turrentine MW. Truncus arteriosus repair: 428 outcomes, risk factors, reoperation and management. Eur J Cardiothorac Surg. 2001;20(2):221-7.

429 7. Hanley FL, Heinemann MK, Jonas RA, Mayer JE, Jr., Cook NR, Wessel DL, Castaneda

430 AR. Repair of truncus arteriosus in the neonate. J Thorac Cardiovasc Surg. 1993;105(6):1047-56.

431 8. Russell HM, Pasquali SK, Jacobs JP, Jacobs ML, O'Brien SM, Mavroudis C, Backer CL.

432 Outcomes of repair of common arterial trunk with truncal valve surgery: a review of the society

433 of thoracic surgeons congenital heart surgery database. Ann Thorac Surg. 2012;93(1):164-9.

$4349 . \quad$ Mastropietro CW, Amula V, Sassalos P, Buckley JR, Smerling AJ, Iliopoulos I, Riley

435 CM, Jennings A, Cashen K, Narasimhulu SS, Narayana Gowda KM, Bakar AM, Wilhelm M, 436 Badheka A, Moser EAS, Costello JM. Characteristics and operative outcomes for children 
437 undergoing repair of truncus arteriosus: A contemporary multicenter analysis. J Thorac

438 Cardiovasc Surg. 2019;157(6):2386-98.

439 10. Laohaprasitiporn D, Treeratanapaiboon N, Nana A, Soongswang J, Durongpisitkul K, 440 Chanthong P, Phrudprisan S. Truncus Arteriosus: Siriraj Experience. Siriraj Med J. 2008;60(2):4.

441 11. Urban AE, Sinzobahamvya N, Brecher AM, Wetter J, Malorny S. Truncus arteriosus: 442 ten-year experience with homograft repair in neonates and infants. Ann Thorac Surg. 1998;66(6 443 Suppl):S183-8.

444 12. Brizard CP, Cochrane A, Austin C, Nomura F, Karl TR. Management strategy and long445 term outcome for truncus arteriosus. Eur J Cardiothorac Surg. 1997;11(4):687-96.

446 13. Lacour-Gayet F, Serraf A, Komiya T, Sousa-Uva M, Bruniaux J, Touchot A, Roux D, 447 Neuville P, Planche C. Truncus arteriosus repair: influence of techniques of right ventricular 448 outflow tract reconstruction. J Thorac Cardiovasc Surg. 1996;111(4):849-56.

449 14. Naimo PS, Fricke TA, Yong MS, d'Udekem Y, Kelly A, Radford DJ, Bullock A, 450 Weintraub RG, Brizard CP, Konstantinov IE. Outcomes of Truncus Arteriosus Repair in 451 Children: 35 Years of Experience From a Single Institution. Semin Thorac Cardiovasc Surg. $452 \quad 2016 ; 28(2): 500-11$.

453 15. Ivanov Y, Mykychak Y, Fedevych O, Motrechko O, Kurkevych A, Yemets I. Single454 centre 20-year experience with repair of truncus arteriosus. Interact Cardiovasc Thorac Surg. $455 \quad 2019 ; 29(1): 93-100$.

456 16. Arslan AH, Ugurlucan M, Yildiz Y, Ay S, Bahceci F, Besikci R, Cicek S. Surgical 457 treatment of common arterial trunk in patients beyond the first year of life. World J Pediatr 458 Congenit Heart Surg. 2014;5(2):211-5. 
459 17. Chen Q, Gao H, Hua Z, Yang K, Yan J, Zhang H, Ma K, Zhang S, Qi L, Li S. Outcomes 460 of Surgical Repair for Persistent Truncus Arteriosus from Neonates to Adults: A Single Center's 461 Experience. PLoS One. 2016;11(1):e0146800.

462 18. Asagai S, Inai K, Shinohara T, Tomimatsu H, Ishii T, Sugiyama H, Park IS, Nagashima 463 M, Nakanishi T. Long-term Outcomes after Truncus Arteriosus Repair: A Single-center 464 Experience for More than 40 Years. Congenit Heart Dis. 2016;11(6):672-7.

465 19. Morgan CT, Tang A, Fan CP, Golding F, Manlhiot C, van Arsdell G, Honjo O, Jaeggi E. 466 Contemporary Outcomes and Factors Associated With Mortality After a Fetal or Postnatal 467 Diagnosis of Common Arterial Trunk. Can J Cardiol. 2019;35(4):446-52.

468 20. Rajasinghe HA, McElhinney DB, Reddy VM, Mora BN, Hanley FL. Long-term follow469 up of truncus arteriosus repaired in infancy: a twenty-year experience. J Thorac Cardiovasc Surg. $470 \quad 1997 ; 113(5): 869-79$.

471 21. Poynter JA, Eghtesady P, McCrindle BW, Walters HL, 3rd, Kirshbom PM, Blackstone 472 EH, Husain SA, Overman DM, Austin EH, Karamlou T, Lodge AJ, St Louis JD, Gruber PJ, 473 Ziemer G, Davies RR, Jacobs JP, Brown JW, Williams WG, Tchervenkov CI, Jacobs ML, 474 Caldarone CA. Association of pulmonary conduit type and size with durability in infants and 475 young children. Ann Thorac Surg. 2013;96(5):1695-702.

476 22. Hickey EJ, McCrindle BW, Blackstone EH, Yeh T, Jr., Pigula F, Clarke D, Tchervenkov 477 CI, Hawkins J. Jugular venous valved conduit (Contegra) matches allograft performance in 478 infant truncus arteriosus repair. Eur J Cardiothorac Surg. 2008;33(5):890-8.

479 23. Barbero-Marcial M, Tanamati C. Alternative nonvalved techniques for repair of truncus 480 arteriosus: Long-term results. Semin Thorac Cardiovasc Surg Pediatr Card Surg Annu. $481 \quad 1999 ; 2: 121-30$. 
482 24. Raisky O, Ali WB, Bajolle F, Marini D, Metton O, Bonnet D, Sidi D, Vouhe PR.

483 Common arterial trunk repair: with conduit or without? Eur J Cardiothorac Surg.

$484 \quad 2009 ; 36(4): 675-82$.

485 25. Niwa K, Perloff JK, Kaplan S, Child JS, Miner PD. Eisenmenger syndrome in adults:

486 ventricular septal defect, truncus arteriosus, univentricular heart. J Am Coll Cardiol.

$487 \quad 1999 ; 34(1): 223-32$.

488 26. Williams JM, de Leeuw M, Black MD, Freedom RM, Williams WG, McCrindle BW.

489 Factors associated with outcomes of persistent truncus arteriosus. J Am Coll Cardiol.

$490 \quad 1999 ; 34(2): 545-53$.

491 
Figure 1

Flow of study

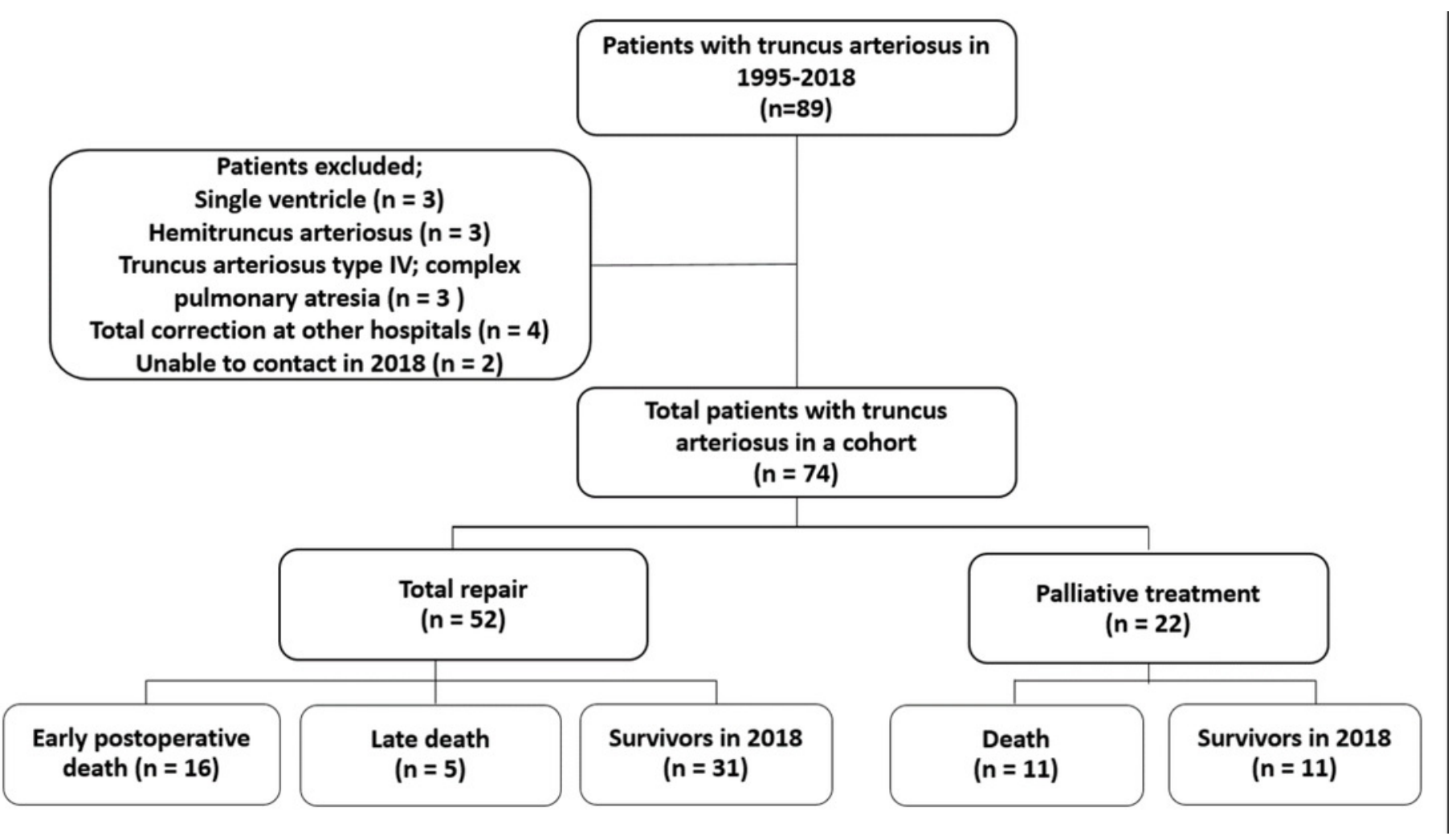




\section{Table 1 (on next page)}

Patients' characteristics $(n=74)$

Data represented by median (range), mean \pm SD and number (\% within column) Statistically significant at $p$-value $<0.05$ by Chi-square or Fisher's exact test and independent T test (for normally distributed data) or Wilcoxon rank-sum test (for non-normally distributed data) TA, truncus arteriosus 
1 Table 1 Patients' characteristics $(n=74)$

\begin{tabular}{|c|c|c|c|c|}
\hline Variable & $\begin{array}{l}\text { All patients } \\
(\mathrm{n}=74)\end{array}$ & $\begin{array}{l}\text { Repaired TA } \\
(\mathrm{n}=52)\end{array}$ & $\begin{array}{c}\text { Unrepaired } \\
\text { TA } \\
(\mathrm{n}=22)\end{array}$ & $p$-value \\
\hline Male gender & $34(45.9 \%)$ & $25(48.1 \%)$ & $9(40.9 \%)$ & 0.57 \\
\hline $\begin{array}{l}\text { Age at suspicion of TA at } \\
\text { primary hospital (years) }\end{array}$ & $\begin{array}{c}0.05 \\
(0-25.91)\end{array}$ & $\begin{array}{c}0.05 \\
(0-2.01)\end{array}$ & $\begin{array}{c}0.07 \\
(0-25.91)\end{array}$ & 0.79 \\
\hline $\begin{array}{l}\text { Age at referral and } \\
\text { diagnosis of TA at the } \\
\text { center (years) }\end{array}$ & $\begin{array}{c}0.19 \\
(0-25.91)\end{array}$ & $\begin{array}{c}0.16 \\
(0-2.01)\end{array}$ & $\begin{array}{c}1.85 \\
(0-25.91)\end{array}$ & 0.07 \\
\hline Body weight at referral (kg) & $\begin{array}{c}3.67 \\
(1.50-48.00)\end{array}$ & $\begin{array}{c}3.38 \\
(1.50-9.40)\end{array}$ & $\begin{array}{c}8.05 \\
(2.30-48.00)\end{array}$ & 0.05 \\
\hline Oxygen saturation, $\%$ & $88.88 \pm 5.86$ & $90.33 \pm 4.68$ & $85.45 \pm 6.96$ & $0.005 *$ \\
\hline $\begin{array}{l}\text { Cardiothoracic ratio on } \\
\text { chest radiography }\end{array}$ & $0.62 \pm 0.05$ & $0.62 \pm 0.04$ & $0.63 \pm 0.06$ & 0.42 \\
\hline Prenatal diagnosis & $4(5.4 \%)$ & $3(5.7 \%)$ & $1(4.5 \%)$ & 1.00 \\
\hline $\begin{array}{l}\text { Associated anomalies } \\
\text { - DiGeorge syndrome }\end{array}$ & $\begin{array}{l}24(32.4 \%) \\
10(13.5 \%)\end{array}$ & $\begin{array}{l}18(34.6 \%) \\
8(15.4 \%)\end{array}$ & $\begin{array}{l}6(27.3 \%) \\
2(9.1 \%)\end{array}$ & $\begin{array}{l}0.53 \\
0.47\end{array}$ \\
\hline $\begin{array}{ll}\text { TA type (Collett and } \\
\text { Edwards) } \\
\begin{array}{ll}\text { - } & \text { Type I } \\
- & \text { Type II } \\
- & \text { Type III } \\
\end{array}\end{array}$ & $\begin{array}{c}54(72.9 \%) \\
17(23.0 \%) \\
3(4.1 \%)\end{array}$ & $\begin{array}{l}37(71.1 \%) \\
13(25 \%) \\
2(3.9 \%)\end{array}$ & $\begin{array}{c}17(77.3 \%) \\
4(18.2 \%) \\
1(4.5 \%)\end{array}$ & 0.58 \\
\hline \begin{tabular}{cl}
\multicolumn{2}{l}{ Truncal valve leaflets } \\
- & Bicuspid \\
- & Tricuspid \\
- & Quardricuspid
\end{tabular} & $\begin{array}{l}14(19.0 \%) \\
40(54.0 \%) \\
20(27.0 \%\end{array}$ & $\begin{array}{c}9(17.3 \%) \\
31(59.6 \%) \\
12(23.1 \%)\end{array}$ & $\begin{array}{l}5(22.7 \%) \\
9(40.9 \%) \\
8(36.4 \%)\end{array}$ & 0.84 \\
\hline $\begin{array}{l}\text { Presence of moderate and } \\
\text { severe truncal valve } \\
\text { regurgitation }\end{array}$ & $5(6.7 \%)$ & $4(7.7 \%)$ & $1(4.5 \%)$ & 1.00 \\
\hline $\begin{array}{l}\text { Presence of pulmonary } \\
\text { artery stenosis }\end{array}$ & $6(8.1 \%)$ & $5(9.6 \%)$ & $1(4.5 \%)$ & 0.66 \\
\hline $\begin{array}{l}\text { Presence of interrupted } \\
\text { aortic arch }\end{array}$ & $2(2.7 \%)$ & $1(1.9 \%)$ & $1(4.5 \%)$ & 0.51 \\
\hline $\begin{array}{l}\text { Presence of right side aortic } \\
\text { arch }\end{array}$ & $22(29.7 \%)$ & $17(32.7 \%)$ & $5(22.7 \%)$ & 0.35 \\
\hline $\begin{array}{l}\text { Presence of partial } \\
\text { anomalous pulmonary } \\
\text { venous return }\end{array}$ & $4(5.4 \%)$ & $4(7.7 \%)$ & 0 & 0.31 \\
\hline $\begin{array}{l}\text { Left ventricular ejection } \\
\text { fraction }(\%)\end{array}$ & $66.99 \pm 8.90$ & $68.53 \pm 8.09$ & $62.80 \pm 9.86$ & $0.015 *$ \\
\hline
\end{tabular}

2 Data represented by median (range), mean \pm SD and number (\% within column)

3 Statistically significant at $p$-value $<0.05$ by Chi-square or Fisher's exact test and independent T 4 test (for normally distributed data) or Wilcoxon rank-sum test (for non-normally distributed data) 5 TA, truncus arteriosus 


\section{Table 2 (on next page)}

Demographics, operative data and early postoperative course of patients who underwent truncus arteriosus repair $(n=52)$

Data represented by median (range), mean \pm SD and number (\% within column) Statistically significant at $p$-value $<0.05$ by Chi-square or Fisher's exact test and independent T test (for normally distributed data) or Wilcoxon rank-sum test (for non-normally distributed data) TA, truncus arteriosus; ECMO, extracorporeal membrane oxygenator 
1 Table 2 Demographics, operative data and early postoperative course of patients who underwent

2 truncus arteriosus repair $(\mathrm{n}=52)$

\begin{tabular}{|c|c|c|c|c|}
\hline Variable & $\begin{array}{l}\text { All TA repair } \\
\quad(\mathrm{n}=52)\end{array}$ & $\begin{array}{l}\text { Mortality } \\
(\mathrm{n}=21)\end{array}$ & $\begin{array}{l}\text { Survivors in } \\
2018(n=31)\end{array}$ & $p$-value \\
\hline Male gender & $25(48.1 \%)$ & $9(42.9 \%)$ & $16(51.6 \%)$ & 0.53 \\
\hline Prenatal diagnosis & $3(5.7 \%)$ & $2(9.5 \%)$ & $1(3.2 \%)$ & 0.55 \\
\hline Age at surgery (days) & $133(22-6111)$ & $88(22-319)$ & $189(48-6111)$ & 0.11 \\
\hline Weight at total repair $(\mathrm{kg})$ & $4.2(2.2-38.0)$ & $3.6(2.2-6.5)$ & $5.1(2.9-38.0)$ & 0.06 \\
\hline $\begin{array}{l}\text { Associated anomalies } \\
\text { - } \quad \text { DiGeorge syndrome }\end{array}$ & $\begin{array}{l}18(34.6 \%) \\
8(15.4 \%)\end{array}$ & $\begin{array}{l}11(52.4 \%) \\
4(19.0 \%)\end{array}$ & $\begin{array}{l}7(22.5 \%) \\
4(12.9 \%)\end{array}$ & $\begin{array}{c}0.027^{*} \\
0.54\end{array}$ \\
\hline $\begin{array}{l}\text { TA type I (Collett and } \\
\text { Edward) }\end{array}$ & $37(71.1 \%)$ & $13(61.9 \%)$ & $24(77.4 \%)$ & 0.23 \\
\hline $\begin{array}{l}\text { Presence of moderate and } \\
\text { severe truncal valve } \\
\text { regurgitation }\end{array}$ & $4(7.7 \%)$ & $3(14.3 \%)$ & $1(3.2 \%)$ & 0.29 \\
\hline $\begin{array}{l}\text { Presence of pulmonary artery } \\
\text { stenosis }\end{array}$ & $5(9.6 \%)$ & $3(14.3 \%)$ & $2(6.5 \%)$ & 0.38 \\
\hline $\begin{array}{l}\text { Presence of interrupted aortic } \\
\text { arch }\end{array}$ & $1(1.9 \%)$ & $1(4.7 \%)$ & 0 & 0.40 \\
\hline $\begin{array}{l}\text { Presence of right side aortic } \\
\text { arch }\end{array}$ & $17(32.7 \%)$ & $7(33.3 \%)$ & $10(32.6 \%)$ & 0.93 \\
\hline $\begin{array}{l}\text { Presence of partial anomalous } \\
\text { pulmonary venous return }\end{array}$ & $4(7.7 \%)$ & 0 & $4(12.9 \%)$ & 0.13 \\
\hline $\begin{array}{l}\text { Presence of coronary } \\
\text { abnormalities }\end{array}$ & $8(15.4 \%)$ & $4(19.0 \%)$ & $4(12.9 \%)$ & 0.54 \\
\hline $\begin{array}{l}\text { Pulmonary artery banding } \\
\text { prior to repair }\end{array}$ & $3(5.8 \%)$ & $1(4.8 \%)$ & $2(6.5 \%)$ & 1.00 \\
\hline $\begin{array}{l}\text { Preoperative major infection } \\
\text { within } 1 \text { month }\end{array}$ & $10(19.2 \%)$ & $7(33.3 \%)$ & $3(9.7 \%)$ & $0.03 *$ \\
\hline $\begin{array}{l}\text { Preoperative being on } \\
\text { mechanical ventilator }\end{array}$ & $2(3.8 \%)$ & $1(4.8 \%)$ & $1(3.2 \%)$ & 1.00 \\
\hline \multicolumn{5}{|l|}{ Operative data } \\
\hline Surgical era 1999-2006 & $15(28.8 \%)$ & $7(33.3 \%)$ & $8(25.8 \%)$ & 0.55 \\
\hline $\begin{array}{l}\text { Cardiopulmonary bypass time } \\
\text { (min) }\end{array}$ & $169.6 \pm 43.8$ & $181.3 \pm 51.1$ & $161.7 \pm 36.9$ & 0.07 \\
\hline Aortic clamp time (min) & $107.2 \pm 29.6$ & $105.8 \pm 26.6$ & $108.1 \pm 31.9$ & 0.79 \\
\hline Truncal valve repaired & $4(7.7 \%)$ & $3(14.3 \%)$ & $1(3.2 \%)$ & 0.14 \\
\hline Aortic arch repaired & $1(1.9 \%)$ & $1(4.8 \%)$ & 0 & 0.22 \\
\hline Conduit size (mm) & $14.2 \pm 3.1$ & $12.9 \pm 2.9$ & $15.0 \pm 2.9$ & $0.01^{*}$ \\
\hline Conduit size $\mathrm{z}$-score & $2.3 \pm 0.9$ & $2.3 \pm 0.8$ & $2.3 \pm 1.0$ & 0.89 \\
\hline $\begin{array}{l}\text { Type of conduit } \\
\text { - Aortic homograft } \\
\text { - Pulmonary homograft }\end{array}$ & $\begin{array}{c}5(9.6 \%) \\
10(19.2 \%)\end{array}$ & $\begin{array}{c}0 \\
3(14.3 \%)\end{array}$ & $\begin{array}{l}5(16.1 \%) \\
7(22.6 \%)\end{array}$ & 0.18 \\
\hline
\end{tabular}




\begin{tabular}{|c|c|c|c|c|}
\hline $\begin{array}{l}\text { - Handcock / Carpentier- } \\
\text { Edwards valved conduit } \\
\text { - Contegra bovine jugular } \\
\text { valved conduit } \\
\text {-Direct anastomosis with } \\
\text { monocusp }\end{array}$ & $\begin{array}{c}24(46.2 \%) \\
1(1.9 \%)\end{array}$ & $\begin{array}{c}12(57.1 \%) \\
1(4.8 \%)\end{array}$ & $\begin{array}{c}7(22.6 \%) \\
12(38.7 \%) \\
0\end{array}$ & \\
\hline $\begin{array}{l}\text { Intraoperative usage of } \\
\text { inhaled nitric oxide }\end{array}$ & $9(17.3 \%)$ & $6(28.5 \%)$ & $3(9.6 \%$ & 0.07 \\
\hline \multicolumn{5}{|l|}{ Early postoperative course } \\
\hline Postoperative ECMO & $4(7.7 \%)$ & $4(19.0 \%)$ & 0 & $0.02 *$ \\
\hline $\begin{array}{l}\text { Postoperative usage of } \\
\text { inhaled nitric oxide }\end{array}$ & $34(65.4 \%)$ & $16(76.2 \%)$ & $18(58.1 \%)$ & 0.17 \\
\hline $\begin{array}{l}\text { Postoperative acute kidney } \\
\text { injury requiring renal } \\
\text { replacement therapy }\end{array}$ & $14(26.9 \%)$ & $11(52.4 \%)$ & $3(9.7 \%)$ & $0.001 *$ \\
\hline Postoperative pneumonia & $24(46.2 \%)$ & $8(38.1 \%)$ & $16(51.6 \%)$ & 0.34 \\
\hline Postoperative septicemia & $10(19.2 \%)$ & $6(28.6 \%)$ & $4(12.9 \%)$ & 0.16 \\
\hline $\begin{array}{l}\text { Postoperative fatal } \\
\text { arrhythmia }\end{array}$ & $4(7.7 \%)$ & $4(19.0 \% 0$ & 0 & $0.02 *$ \\
\hline Total intensive care unit stay & $8.5(1-167)$ & $5(1-134)$ & $11(1-167)$ & 0.59 \\
\hline Total hospital length of stay & $23(1-206)$ & $12(1-151)$ & $24(9-206)$ & 0.99 \\
\hline
\end{tabular}

3 Data represented by median (range), mean \pm SD and number (\% within column)

4 Statistically significant at $p$-value $<0.05$ by Chi-square or Fisher's exact test and independent T

5 test (for normally distributed data) or Wilcoxon rank-sum test (for non-normally distributed data)

6 TA, truncus arteriosus; ECMO, extracorporeal membrane oxygenator

7 


\section{Table 3 (on next page)}

Characteristics and causes of death following operation $(n=21)$

TA, truncus arteriosus; PH crisis, pulmonary hypertensive crisis; LCOS, low cardiac output syndrome; AKI, acute kidney injury; ECMO, extracorporeal membrane oxygenator; PAH, pulmonary arterial hypertension; VT, ventricular tachycardia; VF, ventricular fibrillation; IAA, interrupted aortic arch; VSD, ventricular septal defect 
1 Table 3 Characteristics and causes of death following operation $(n=21)$

\begin{tabular}{|c|c|c|c|c|c|c|c|}
\hline ID & $\begin{array}{l}\text { Opera } \\
\text { tion } \\
\text { year }\end{array}$ & Gender & $\begin{array}{c}\text { Associated } \\
\text { anomalies }\end{array}$ & $\begin{array}{l}\text { Age at } \\
\text { repair } \\
\text { (days) }\end{array}$ & $\begin{array}{l}\text { Interval } \\
\text { post } \\
\text { operation } \\
\text { (days) }\end{array}$ & $\begin{array}{l}\text { Repaired } \\
\text { TA type }\end{array}$ & Cause of death \\
\hline 64 & 2003 & Male & None & 133 & 1 & Type I & $\begin{array}{l}\text { Early } \\
\text { postoperative } \mathrm{PH} \\
\text { crisis }\end{array}$ \\
\hline 50 & 2004 & Female & None & 47 & 1 & Type II & $\begin{array}{l}\text { Early } \\
\text { postoperative } \\
\text { LCOS, myocardial } \\
\text { failure, AKI, } \\
\text { possible PH crisis, } \\
\text { myocardial } \\
\text { ischemia }\end{array}$ \\
\hline 62 & 2004 & Female & Microcephaly & 92 & 2 & Type I & $\begin{array}{l}\text { Early } \\
\text { postoperative PH } \\
\text { crisis, } \\
\text { hemopericardium }\end{array}$ \\
\hline 85 & 2004 & Female & $\begin{array}{l}\text { Congenital } \\
\text { iris cyst }\end{array}$ & 49 & 14 & Type I & $\begin{array}{l}\text { Early } \\
\text { postoperative PH } \\
\text { crisis, sepsis, } \\
\text { pneumonia, atrial } \\
\text { tachycardia, } \\
\text { idioventricular } \\
\text { rhythm }\end{array}$ \\
\hline 22 & 2005 & Female & None & 47 & 0 & $\begin{array}{l}\text { Type III } \\
\text { with } \\
\text { proximal } \\
\text { pulmonary } \\
\text { artery } \\
\text { stenosis } \\
\end{array}$ & $\begin{array}{l}\text { Early } \\
\text { postoperative } \mathrm{PH} \\
\text { crisis }\end{array}$ \\
\hline 86 & 2007 & Male & None & 135 & 4 & Type III & $\begin{array}{l}\text { Early } \\
\text { postoperative PH } \\
\text { crisis, AKI }\end{array}$ \\
\hline 60 & 2008 & Male & $\begin{array}{l}\text { DiGeorge } \\
\text { syndrome }\end{array}$ & 319 & 380 & Type I & $\begin{array}{l}\text { Late mortality due } \\
\text { to Persistent PAH } \\
\text { post-operation, } \\
\text { infection, } \\
\text { pneumonia }\end{array}$ \\
\hline 46 & 2009 & Female & None & 86 & 1 & Type I & $\begin{array}{l}\text { Early } \\
\text { postoperative } \\
\text { myocardial failure } \\
\text { possible } \\
\text { myocardial }\end{array}$ \\
\hline
\end{tabular}




\begin{tabular}{|c|c|c|c|c|c|c|c|}
\hline & & & & & & & $\begin{array}{l}\text { ischemia, JET, AV } \\
\text { block }\end{array}$ \\
\hline 61 & 2011 & Male & None & 67 & 0 & $\begin{array}{l}\text { Type I, } \\
\text { repaired } \\
\text { truncal } \\
\text { valve }\end{array}$ & $\begin{array}{l}\text { Early } \\
\text { postoperative PH } \\
\text { crisis, LCOS, VT, } \\
\text { VF }\end{array}$ \\
\hline 23 & 2012 & Female & $\begin{array}{l}\text { Ex preterm, } \\
\text { congenital } \\
\text { hypothyroid }\end{array}$ & 184 & 8 & Type I & $\begin{array}{l}\text { PH crisis, } \\
\text { myocardial failure, } \\
\text { prolonged CBP on } \\
\text { ECMO }\end{array}$ \\
\hline 24 & 2013 & Male & $\begin{array}{l}\text { Ex preterm, } \\
\text { hypospadias }\end{array}$ & 77 & 459 & Type I & $\begin{array}{l}\text { Late mortality, } \\
\text { persistent PAH } \\
\text { post-operation, } \\
\text { conduit failure, } \\
\text { redo conduit } \\
\text { change and died } \\
\text { due to pneumonia } \\
\text { post reoperation } 2 \\
\text { months) }\end{array}$ \\
\hline 19 & 2013 & Female & $\begin{array}{l}\text { Fetal alcohol } \\
\text { syndrome }\end{array}$ & 90 & 219 & Type II & $\begin{array}{l}\text { Late mortality: } \\
\text { septic shock }\end{array}$ \\
\hline 78 & 2013 & Male & None & 134 & 5 & $\begin{array}{c}\text { Type I, } \\
\text { post } \\
\text { pulmonary } \\
\text { artery } \\
\text { banding } \\
\end{array}$ & $\begin{array}{l}\text { Early } \\
\text { postoperative } \mathrm{PH} \\
\text { crisis }\end{array}$ \\
\hline 93 & 2014 & Male & $\begin{array}{c}\text { Complete } \\
\text { bilateral cleft } \\
\text { lips and cleft } \\
\text { palate }\end{array}$ & 60 & 25 & Type II & $\begin{array}{l}\text { Early } \\
\text { postoperative PH } \\
\text { crisis, LCOS on } \\
\text { ECMO, severe } \\
\text { intrathoracic } \\
\text { infection, bowel } \\
\text { ischemia, septic } \\
\text { shock }\end{array}$ \\
\hline 26 & 2014 & Female & $\begin{array}{l}\text { Tracheoesop } \\
\text { hageal fistula }\end{array}$ & 22 & 168 & Type I & $\begin{array}{l}\text { Late mortality: } \\
\text { sepsis, pneumonia }\end{array}$ \\
\hline 25 & 2015 & Male & None & 115 & 40 & Type I & $\begin{array}{l}\text { In-hospital } \\
\text { mortality, } \\
\text { postoperative } \\
\text { septic shock, } \\
\text { pneumonia }\end{array}$ \\
\hline 83 & 2015 & Female & None & 251 & 0 & Type II & $\begin{array}{l}\text { Early } \\
\text { postoperative PH } \\
\text { crisis, VT, VF, } \\
\text { arrest on ECMO, } \\
\text { cardiac tamponade }\end{array}$ \\
\hline
\end{tabular}




\begin{tabular}{|c|c|c|c|c|c|c|c|}
\hline 31 & 2015 & Female & None & 93 & 1 & $\begin{array}{c}\text { Type II + } \\
\text { repaired } \\
\text { IAA, } \\
\text { multiple } \\
\text { small } \\
\text { muscular } \\
\text { VSD left } \\
\text { opened }\end{array}$ & $\begin{array}{l}\text { Early } \\
\text { postoperative PH } \\
\text { crisis }\end{array}$ \\
\hline 20 & 2015 & Male & $\begin{array}{l}\text { DiGeorge } \\
\text { syndrome, } \\
\text { hypospadia }\end{array}$ & 36 & 214 & Type I & $\begin{array}{l}\text { Late mortality: } \\
\text { sepsis, pneumonia }\end{array}$ \\
\hline 21 & 2016 & Female & $\begin{array}{l}\text { DiGeorge } \\
\text { syndrome }\end{array}$ & 88 & 7 & Type II & $\begin{array}{l}\text { Early } \\
\text { postoperative PH } \\
\text { crisis }\end{array}$ \\
\hline 92 & 2018 & Female & $\begin{array}{l}\text { VACTREL } \\
\text { association, } \\
\text { rib anomaly, } \\
\text { hemivertebra }\end{array}$ & 27 & 4 & $\begin{array}{c}\text { Type I + } \\
\text { repaired } \\
\text { truncal } \\
\text { valve }\end{array}$ & $\begin{array}{l}\text { Early } \\
\text { postoperative PH } \\
\text { crisis, sepsis, } \\
\text { pneumonia }\end{array}$ \\
\hline
\end{tabular}

2 TA, truncus arteriosus; PH crisis, pulmonary hypertensive crisis; LCOS, low cardiac output

3 syndrome; AKI, acute kidney injury; ECMO, extracorporeal membrane oxygenator; PAH,

4 pulmonary arterial hypertension; VT, ventricular tachycardia; VF, ventricular fibrillation; IAA,

5 interrupted aortic arch; VSD, ventricular septal defect 


\section{Table 4(on next page)}

Predictors of overall postoperative mortality $(n=52)$

Univariate and multivariate analysis by cox regression Statistically significant at $p$-value < $0.05 \mathrm{HR}$, hazard ratio; TA, truncus arteriosus; CBP, cardiopulmonary bypass 
2 Table 4 Predictors of overall postoperative mortality $(n=52)$

\begin{tabular}{|c|c|c|c|c|}
\hline Variables & $\begin{array}{l}\text { Crude HR } \\
(95 \% \text { CI })\end{array}$ & $p$-value & $\begin{array}{l}\text { Adjusted HR } \\
(95 \% C I)\end{array}$ & $p$-value \\
\hline Male gender & $0.69(0.29-1.66)$ & 0.42 & & \\
\hline $\begin{array}{l}\text { Presence of associated } \\
\text { anomaly }\end{array}$ & $2.06(0.87-4.66)$ & 0.09 & $\begin{array}{l}1.52(0.59- \\
3.87)\end{array}$ & 0.38 \\
\hline DiGeorge syndrome & $1.16(0.39-3.45)$ & 0.78 & & \\
\hline Prenatal diagnosis & $1.65(0.38-7.14)$ & 0.49 & & \\
\hline Weight at operation $<4 \mathrm{~kg}$. & $3.18(1.31-7.71)$ & $0.01 *$ & $\begin{array}{l}2.71(1.05- \\
6.95) \\
\end{array}$ & $0.039 *$ \\
\hline TA type II and III & $0.59(0.25-1.43)$ & 0.25 & & \\
\hline $\begin{array}{l}\text { Presence of moderate and } \\
\text { severe truncal valve } \\
\text { regurgitation }\end{array}$ & $2.26(0.66-7.78)$ & 0.19 & & \\
\hline $\begin{array}{l}\text { Presence of pulmonary artery } \\
\text { stenosis }\end{array}$ & $0.63(0.18-2.17)$ & 0.47 & & \\
\hline $\begin{array}{l}\text { Presence of interrupted aortic } \\
\text { arch }\end{array}$ & $\begin{array}{c}4.66(0.59- \\
36.41) \\
\end{array}$ & 0.14 & & \\
\hline $\begin{array}{l}\text { Presence of partial } \\
\text { anomalous pulmonary venous } \\
\text { return }\end{array}$ & $0.04(0-24.57)$ & 0.33 & & \\
\hline $\begin{array}{l}\text { Presence of coronary } \\
\text { abnormalities }\end{array}$ & $1.61(0.54-4.81)$ & 0.38 & & \\
\hline $\begin{array}{l}\text { Pulmonary artery banding } \\
\text { prior to repair }\end{array}$ & $0.71(0.09-5.3)$ & 0.79 & & \\
\hline $\begin{array}{l}\text { Preoperative major infection } \\
\text { within } 1 \text { month }\end{array}$ & $2.42(1.0-6.04)$ & $0.05^{*}$ & $\begin{array}{l}1.23(0.42- \\
3.61)\end{array}$ & 0.69 \\
\hline $\begin{array}{l}\text { Preoperative being on } \\
\text { mechanical ventilator }\end{array}$ & $1.1(0.15-8.61)$ & 0.88 & & \\
\hline Operation in 1997-2006 & $1.39(0.56-3.45)$ & 0.47 & & \\
\hline CBP time $>150$ minutes & $0.45(0.15-1.32)$ & 0.14 & & \\
\hline $\begin{array}{l}\text { Intraoperative usage of } \\
\text { inhaled nitric oxide }\end{array}$ & $2.24(0.87-5.71)$ & 0.09 & $\begin{array}{l}1.71(0.62- \\
\quad 4.71)\end{array}$ & 0.29 \\
\hline
\end{tabular}

3 Univariate and multivariate analysis by cox regression

4 Statistically significant at $p$-value $<0.05$

5 HR, hazard ratio; TA, truncus arteriosus; CBP, cardiopulmonary bypass 